\title{
Microbial Contamination in Vegetables at the Farm Gate Due to Irrigation with Wastewater in the Tamale Metropolis of Northern Ghana
}

\author{
Samuel Jerry Cobbina ${ }^{1,2^{*}}$, Mohammed Clement Kotochi ${ }^{1}$, Joseph Kudadam Korese ${ }^{3}$, Mark Osa Akrong ${ }^{4}$ \\ ${ }^{1}$ Department of Ecotourism \& Environmental Management, Faculty of Renewable Natural Resources, University for Development \\ Studies, Nyankpala, Ghana; ${ }^{2}$ School of the Environment, Jiangsu University, Zhenjiang, China; ${ }^{3}$ Department of Agricultural Mecha- \\ nization \& Irrigation Technology, Faculty of Agriculture, University for Development Studies, Nyankpala, Ghana; ${ }^{4}$ Environmental \\ Biology \& Health Division, CSIR Water Research Institute, Accra, Ghana. \\ Email: ${ }^{*}$ cobbinasamuel@yahoo.com
}

Received March $1^{\text {st }}, 2013$; revised April $4^{\text {th }}, 2013$; accepted May $2^{\text {nd }}, 2013$

Copyright (C) 2013 Samuel Jerry Cobbina et al. This is an open access article distributed under the Creative Commons Attribution License, which permits unrestricted use, distribution, and reproduction in any medium, provided the original work is properly cited.

\begin{abstract}
The rational for this study was to assess the microbial quality of fresh vegetables at the farm gate of the Water Works road vegetable farm at Gumbihini in the Tamale Metropolis. A total of thirty-six (36) vegetables comprising lettuce, amarantus and cabbages and eight (8) wastewater samples were collected at random and analysed for a period of four months, to assess the microbial contamination level. Samples were analysed for total coliforms, faecal coliforms, E. coli and helminthes eggs. All vegetables sampled during the study period recorded high levels of total and faecal coliform bacteria. Mean faecal coliforms for the various vegetables were as follows; lettuce $3.7 \pm 0.5 \mathrm{CFU} \cdot \mathrm{g}^{-1}$, amarantus $3.5 \pm$ $0.6 \mathrm{CFU} \cdot \mathrm{g}^{-1}$ and cabbage $3.1 \pm 0.6 \mathrm{log} \mathrm{CFU} \cdot \mathrm{g}^{-1}$ fresh weight. $\mathrm{FC}$ levels were above the International Commission on Microbiological Specifications for Foods (ICMSF) recommended level of $3 \log \mathrm{CFU} \cdot \mathrm{g}^{-1}$ fresh weight. E. coli were recorded in lettuce $\left(3.3 \pm 0.6 \log \mathrm{CFU} \cdot \mathrm{g}^{-1}\right.$ fresh weight) and amarantus $\left(0.6 \pm 0.1 \mathrm{log} \mathrm{CFU} \cdot \mathrm{g}^{-1}\right.$ fresh weight) but not in cabbages. Lettuce generally recorded high levels of microbial contamination because of the large surface area occupied by its leaves. Two helminth eggs (Strongiloides stercoralis) were identified in lettuce while four (Ascaris lumbricoides) were identified in wastewater. Microbial loads recorded in wastewater were generally higher than that of vegetables. Since most of these vegetables are eaten fresh or slightly cooked, there is course for concern as public health will be adversely affected. Education of farmers and consumers on food safety has to be intensified to avert a possible outbreak.
\end{abstract}

Keywords: Helminthes; Faecal Coliform; Irrigation Water; Vegetables; E. coli

\section{Introduction}

The use of wastewater for crop production has been increasing worldwide due to the increasing food demand and the changing climatic conditions that are making food production through rainfed agriculture less reliable [1]. The ever increasing worldwide population, especially in urban and peri-urban areas of the developing economies calls for serious thoughts and approaches in meeting the food demand whiles taking care of the environment for sustainable development. In many countries in Sub-Sahara Africa (SSA), urban wastewater is used to irrigate agricultural lands. This way of disposing of urban

"Corresponding author. sewage has several advantages. Wastewater contains a lot of nutrients, which increase crop yields without use of fertilizer $[2,3]$. Furthermore, sewage water is an alternative water source where water is scarce. However, wastewater also contains a variety of chemical substances and microbiological loads from domestic and industrial sources.

Cities in developing countries, including Ghana, are also experiencing this unparalleled population growth. Available reports indicates that, only $4 \%-5 \%$ of the population in Ghana are linked with-infrequently functional-sewage systems and sewerage treatment plants and as a result, large volumes of wastewater is often released untreated into the environment (streams, drains, 
etc.) [4,5]. According to Amoah [6] the use of potable water for vegetable production is constrained because less than $40 \%$ of city dwellers are still without good drinking water. The need for year-round production of vegetables in or near urban areas makes irrigation necessary; hence, farmers in search of water for irrigation often rely on the wastewater for irrigation [5]. This practice though beneficial in its contributions to urban food security and livelihoods, raises also public health concerns due to the risks posed from untreated wastewater to farmers and vegetable consumers [7].

Vegetables can become contaminated with pathogenic organism during growth, harvest, postharvest handling or distribution $[8,9]$. The use of untreated wastewater in irrigation represents an important route for transmission of these pathogenic organisms. The major pathogens associated with the use of highly polluted water are the faecal coliforms, E. coli and eggs of some helminthes such as Ascaris lumbricoides, Trichuris trichura, Hymenolepis diminuta, Fasciola hepatica and Strongyloides whose resistant eggs can be found in the wastewater $[2,10,11]$. According to Ensink [12], farmers and irrigation workers can acquire helminth infections and parasitic diseases due to direct contact with untreated wastewater and contaminated soils especially if exposed for a long duration. It has also been reported that irrigation of salad crops with untreated wastewater caused excess disease (e.g. shigellosis in England) in those who consumed them [13]. Numerous opportunities exist for attachment and penetration of pathogenic bacteria on vegetables (e.g. lettuce) in the field, as well as during harvesting, processing and marketing, especially when a contaminated product is exposed to water or is damaged [14]. The factors controlling the transmission of disease are agronomic; examples of factors are the type of crop grown, irrigation method used to apply wastewater and the cultural and harvesting practices.

Regarding the situation in the Tamale Metropolis, illegal use of raw wastewater for vegetable production has been observed over the past years. The practice is especially common during the dry seasons when vegetables produced through rainfed agriculture are least available [15]. Previous studies have showed the presence of pathogens in vegetables sold in two (2) major markets and wastewater irrigated sites in Ghana [10]. This study therefore sought to increase knowledge in this area by determining the microbiological loads in vegetables produced at the farm gate in the Tamale Metropolis of Northern Region of Ghana. Specifically, the study aimed at quantifying coliform bacteria, Escherichia coli and helminths eggs on vegetables and wastewater used in irrigating the vegetables.

\section{Materials and Methods}

\subsection{Study Area and Sampling}

The study was conducted in the Tamale Metropolis which lies between latitude $9^{\circ} 24^{\prime} 00^{\prime \prime} \mathrm{N}$ and longitude $0^{\circ} 50^{\prime} 00^{\prime \prime} \mathrm{W}$. A total of thirty-six (36) vegetable samples made up of lettuce, cabbages and amarantus locally known as alefu were collected from the Water Works road vegetable farm in Gumbihini (Figure 1). Eight wastewater samples were collected from wastewater used to water vegetables on the farm (Figure 2). Sampling was between the months of December 2011and March 2012. The temperature, $\mathrm{pH}$ and electrical conductivity of irrigation water were analyzed insitu using a $\mathrm{pH} / \mathrm{Con}$ ductivity meter $340 \mathrm{i} / \mathrm{SET}$ (WTW). Irrigation water was collected in $200 \mathrm{~mL}$ sterilized screw-capped glass bottle, kept under ice at a temperature of $4{ }^{\circ} \mathrm{C}$ and transported to the CSIR Water Research Laboratory for bacteriological analysis.

\subsection{Laboratory Analyses}

Irrigation water and vegetable samples were analysed quantitatively for the determination of total coliform,

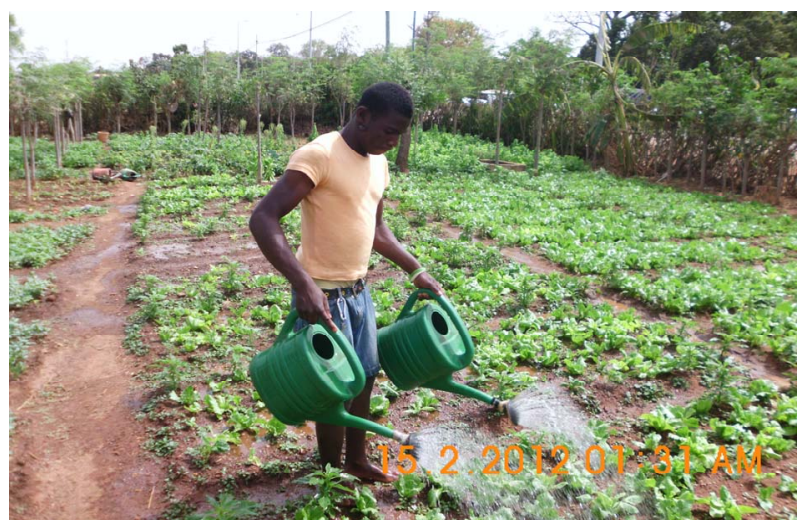

Figure 1. Watering of lettuce at the Waterworks farm.

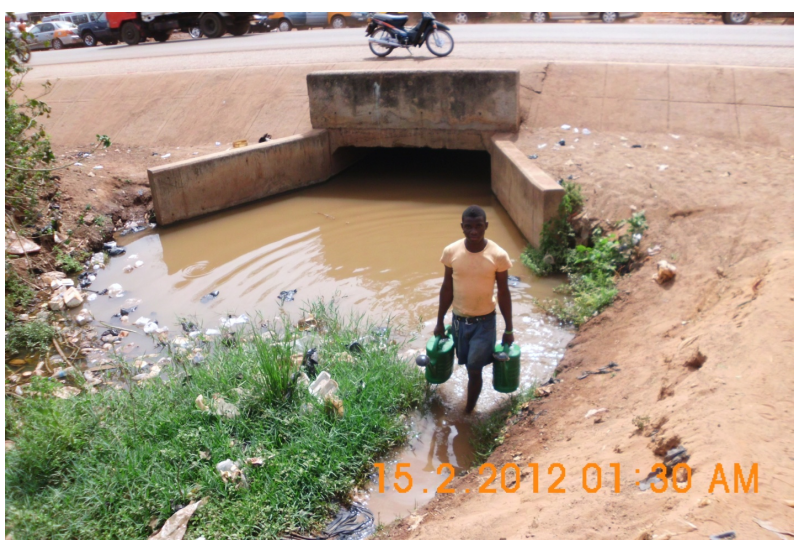

Figure 2. Wastewater used for watering vegetables. 
faecal coliform, E. coli and Helminth eggs. $10 \mathrm{~g}$ of vegetable sample was weighed into $180 \mathrm{~mL}$ of phosphatebuffered saline and rinsed vigorously. The water resulting from the rinsing was used for the determination of total coliform, faecal coliform and E. coli analysis (Figure 3). The Membrane Filtration (MF) technique was used to analyse these parameters. $10 \mathrm{~mL}$ of each of the samples (irrigation water and solution) were separately filtered through a $0.45 \mu \mathrm{m}$ pore size membrane filter. The filter was then placed on M-endo media, MFC media and Hicrome (Difco) media for the detection of total coliform, faecal coliform and E. coli respectively. Incubation was then done at $37^{\circ} \mathrm{C} \pm 0.5^{\circ} \mathrm{C}$ for the determination of total coliform and E. coli, and $44^{\circ} \mathrm{C}$ for faecal coliform determination for $16-24$ hours. Colonies were counted using a colony counter [16].

Helminth eggs were enumerated from the vegetable samples and irrigation water using the concentration method [17]. This is a modified US-EPA method using $\mathrm{ZnSO}_{4}$ solution (specific gravity, 1.2). About $100 \mathrm{~g}$ of vegetable leaves were thoroughly washed in about $1 \mathrm{~L}$ of sterile distilled water. The washed water and irrigation water were then poured into a container and allowed to stand overnight to enable the eggs to settle completely. As much supernatant as possible was sucked up and the sediment transferred into $50 \mathrm{~mL}$ centrifugation tubes. The container was rinsed three times with deinonised water and the rinsed water transferred into the centrifugation tubes. The tubes were then centrifuged at 1450 rpm for 3 mins (Figure 4). The supernatant was poured off and the deposit re-suspended in $40 \mathrm{~mL} \mathrm{ZnSO}_{4}$ solution. The mixture was homogenized with a sterile spatula and centrifuged at $1450 \mathrm{rpm}$. At a specific gravity of 1.2 $\left(\mathrm{ZnSO}_{4}\right)$, helminth eggs float leaving other sediments at the bottom of the centrifuge tube. The $\mathrm{ZnSO}_{4}$ supernatant was poured into a $2 \mathrm{~L}$ flask and distilled water added to the $1 \mathrm{~L}$ mark. This was allowed to stand overnight for the eggs to resettle. As much supernatant as possible was sucked up and the deposit re-suspended by shaking. This was then transferred into a centrifuge tube. The deposit was re-suspended in $15 \mathrm{~mL}$ acid/alcohol buffer solution $\left(\mathrm{H}_{2} \mathrm{SO}_{4}\right.$ at $0.1 \mathrm{~N}$ at $35 \%$ ethanol, i.e., $350 \mathrm{~mL}$ ethanol and $5.16 \mathrm{~mL} \mathrm{H}_{2} \mathrm{SO}_{4}$ ) and about $5 \mathrm{~mL}$ ethyl acetate was added (Figure 4).

The mixture was shaken and the centrifuge tube occasionally opened to let gas out before centrifuging at 2200 rpm for 3 mins. After centrifugation, a diphasic solution (aqueous and lipophilic phase representing the acid/alcohol and ethyl acetate, respectively) was formed. With the aid of a micropipette, large volumes of the supernatant (starting from the lipophilic and then the aqueous phase) were sucked up leaving about $1 \mathrm{~mL}$ of the deposit. The deposit was then transferred onto a Sedgwick-Rafter

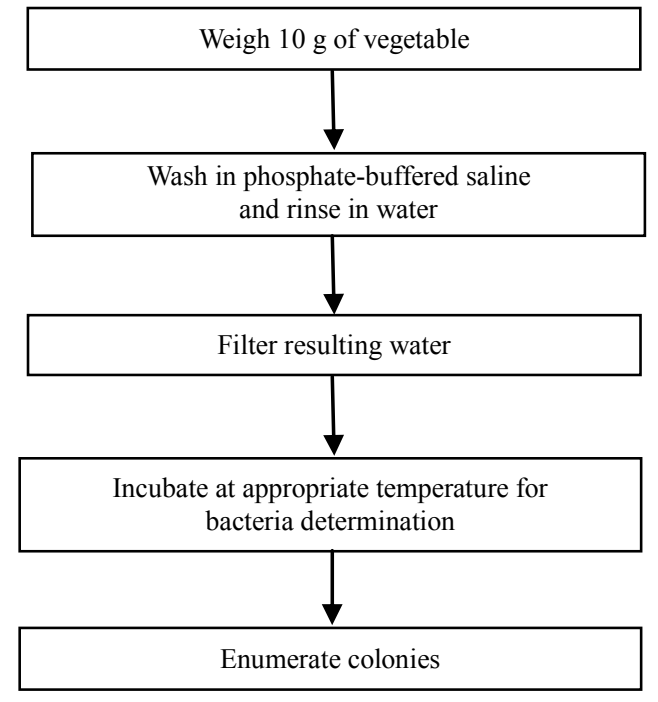

Figure 3. Flow chart showing procedure for determination of bacteria on vegetables.

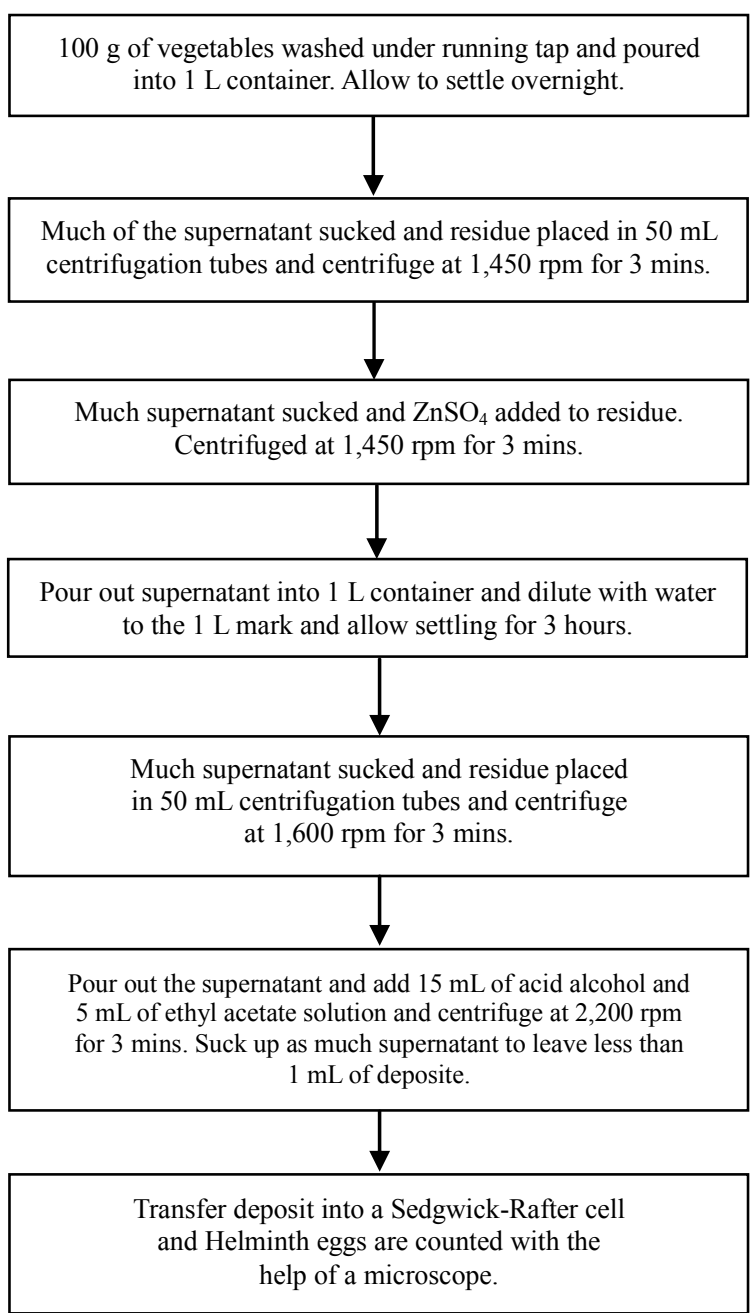

Figure 4. Procedure for the determination of helminth eggs on vegetables. 
cell, observed under a microscope and the eggs counted (Figure 4). Eggs were identified by shape, size and colour. The bench aid for the diagnosis of Intestinal Parasites [18] was used for preliminary identification.

\subsection{Data Analyses}

Geometric means, standard deviations, minimum and maximum values were calculated using SPSS (version 16.0 for Windows). Total coliform, faecal coliform and $E$. coli loads on vegetables and wastewater were normalized by log transforming the raw data before it was analyzed. One way ANOVA was used to assess the statistical differences $(P<0.05)$ between wastewater and vegetables. Correlation analysis was done to determine the source of microbial loads.

\section{Results and Discussions}

The mean microbial loads on vegetables irrigated with wastewater are presented in Table 1. All vegetables sampled during the study period recorded high levels of total and faecal coliform bacteria. The highest level of contamination of total coliform, faecal coliform, E. coli and helminth eggs were recorded on lettuce. Mean levels of total coliforms (TC), faecal coliform (FC), E. coli and Helminthes eggs on lettuce were $4.1 \pm 0.5,3.7 \pm 0.5,3.3$ $\pm 0.6 \log _{10} \mathrm{CFU} \cdot \mathrm{g}^{-1}$ fresh weight and two (2) helminth eggs respectively (Table 1).

The helminth species found in the lettuce was Strongiloides stercoralis. E. coli were detected in lettuce and amarantus, however, none was detected in cabbage during the study period. E. coli detected in lettuce ranged from 2.60 to $4.06 \log \mathrm{CFU} \cdot \mathrm{g}^{-1}$ fresh weight with a mean of $3.3 \pm 0.6 \log \mathrm{CFU} \cdot \mathrm{g}^{-1}$ fresh weight which was higher than the International Commision on Microbiological Specifications for foods (ICMSF) recommended level of $3 \log _{10} \mathrm{CFU} \cdot \mathrm{g}^{-1}$ fresh weight. E. coli levels on amarantus ranged from 0.45 to $0.61 \log _{10} \mathrm{CFU} \cdot \mathrm{g}^{-1}$ fresh weight (mean $0.57 \log \mathrm{CFU} \cdot \mathrm{g}^{-1}$ ). Generally all vegetables recorded faecal coliforms levels higher than ICMSFs recommended limit. Contamination of vegetables on the farm seems to emanate primarily from wastewater used in watering vegetables. According to Abdul-Ghaniyu [15] farmers in the study area usually apply water to their plots using buckets or watering cans. Correlation analysis done indicated a high positive correlation between total coliform on the vegetables and waterwater used for watering (Table 2). Total coliform levels on vegetables showed that they emanate from the same source.

Faecal coliform bacteria levels on vegetables showed a similar trend (Table 3). Faecal coliform loads exhibited a high correlation on both vegetables and wastewater. There was positive correlation between E. coli levels on
Table 1. Mean levels of bacteria on vegetables.

\begin{tabular}{ccccc}
\hline & TC & FC & E .coli & $\begin{array}{c}\text { Helminth } \\
(\text { eggs/l) }\end{array}$ \\
\hline Lettuce & $(3.30-4.73)$ & $(2.98-4.37)$ & $(2.60-4.06)$ & 2 \\
$N=12$ & $4.1 \pm 0.5$ & $3.7 \pm 0.5$ & $3.3 \pm 0.6$ & \\
Amarantus & $(3.20-4.44)$ & $(2.80-4.10)$ & $(0.45-0.61)$ & 0 \\
$N=12$ & $3.8 \pm 0.5$ & $3.4 \pm 0.6$ & $0.6 \pm 0.07$ & \\
Cabbage & $(3.00-4.29)$ & $(2.50-3.80)$ & 0 & 0 \\
$N=12$ & $3.4 \pm 0.2$ & $3.1 \pm 0.6$ & & \\
\hline
\end{tabular}

Units for total coliform (TC), faecal coliform (FC) and E. coli are in $\log _{10}$ $\mathrm{CFU} \cdot \mathrm{g}^{-1}$ fresh weight.

Table 2. Correlation matrix for total coliforms in vegetables and wastewater.

\begin{tabular}{ccccc}
\hline & Lettuce & Amarantus & Cabbage & Wastewater \\
\hline Lettuce & 1 & 0.820 & 0.818 & 0.707 \\
Amarantus & & 1 & 0.872 & 0.717 \\
Cabbage & & & 1 & 0.667 \\
Wastewater & & & & 1 \\
\hline
\end{tabular}

Correlation significant at 0.05 level (2-tailed).

Table 3. Correlation matrix for faecal coliforms on vegetables and wastewater.

\begin{tabular}{ccccc}
\hline & Lettuce & Amarantus & Cabbage & Wastewater \\
\hline Lettuce & 1 & 0.806 & 0.588 & 0.573 \\
Amarantus & & 1 & 0.571 & 0.703 \\
Cabbage & & & 1 & 0.455 \\
Wastewater & & & & 1 \\
\hline
\end{tabular}

Correlation significant at 0.05 level (2-tailed).

lettuce and amarantus $\left(r^{2}=0.667\right)$, amarantus and wastewater $\left(r^{2}=0.660\right)$. However, there was a weak correlation of $E$. coli levels on wastewater and amarantus $\left(r^{2}=\right.$ $0.329)$, implying that the wastewater was not the only source of contamination. Other likely sources of contamination may be from "daefacation" from humans and animals on marginal lands around the farms and from the application of fresh poultry manure on farm plots $[10$, 19].

Bacteria counts on lettuce and amarantus were higher than that on cabbage because of the larger surface area exposed to irrigation water. This confirms work done by Amoah [10] in parts of Ghana. High levels of bacteria in vegetables from the farm gate could be a source of serious health concern to residents. Consumption of contaminated vegetables has been associated with gastrointestinal diseases like typhoid, cholera and dysentery [20-26].

The mean microbial loads in wastewater used to irri- 
gate vegetables in the study area are presented in Table 4. Total coliform composition of wastewater ranged from 3.19 to $4.82 \log$ CFU/100 ml with a mean of $4.4 \log$ $\mathrm{CFU} / 100 \mathrm{ml}$. Faecal coliform bacteria ranged from 3.36 to $4.33 \log \mathrm{CFU} / 100 \mathrm{ml}$ with a mean of $4.0 \log \mathrm{CFU} / 100$ $\mathrm{ml}$. Mean FC was higher than WHO recommended limit of $3 \log$ CFU/100 $\mathrm{ml} \mathrm{[27].}$

Equally, wastewater used for vegetable production in the study area contained $E$.coli ranging from 3.29 to 4.22 $\log$ CFU/100 ml with a mean of $3.7 \log$ CFU/100 ml (Table 4). Four (4) helminthes eggs/l which were of the Ascaris lumbricoides were detected in wastewater during the study period. This exceeded the recommended heleminth level of less than 1 helminth egg/l for unrestricted irrigation [28]. Generally coliform bacteria, E. coli and helminth eggs recoreded in wastewater used for watering of the vegetables were higher than that recorded on the vegetables (Figures 5-8). The poor quality of wastewater in the study area was due to anthropogenic activities such as the disposal of human and animal waste into drains, open defecation around farms and runoffs of fresh poultery manure used to amend soils in the vegetable farms into irrigation water. Using analysis of variance it was observed that there was no significance difference in total coliform bacteria counts in vegetables and wastewater (Figure 5). There were however, significant differences $(P<0.05)$ in faecal coliform counts and E.coli levels in vegetables and wastewater (Figures 5 and 6). $\mathrm{pH}$ and electrical conductivity of wastewater were was good for irrigation.

Helminthes eggs recorded in lettuce and wastewater should be a source of concern, since they pose significant health risk in humans. Generally results of microbial loads in wastewater and vegetables indicate that residents who patronize vegetables from these farms stand a high risk of diseases such as cholera, typhoid and intestinal worms. Data from the Regional Information Management Unit of the Ghana Health Service, Northern Region show reported cases of these diseases (Table 5). Though

Table 4. Physical and bacteriological analysis of wastewater used for watering vegetables.

\begin{tabular}{cccccc}
\hline Parameter & Min & Max & Mean & SD & {$[27]$} \\
\hline Total coliform $(\log \mathrm{CFU} / 100 \mathrm{ml})$ & 3.19 & 4.82 & 4.4 & 0.4 & - \\
Faecal coliform $(\log \mathrm{CFU} / 100 \mathrm{ml})$ & 3.36 & 4.33 & 4.0 & 0.4 & 3 \\
E. coli $(\log \mathrm{CFU} / 100 \mathrm{ml})$ & 3.29 & 4.22 & 3.7 & 0.4 & \\
Helminthes $(\mathrm{eggs} / \mathrm{l})$ & $<1$ & 4 & 1 & - & 0 \\
$\mathrm{pH}$ & 7.01 & 7.40 & 7.24 & & \\
Temperature $\left({ }^{\circ} \mathrm{C}\right)$ & 30.9 & 34.1 & 31.8 & & \\
Conductivity $(\mu \mathrm{S} / \mathrm{cm})$ & 240 & 243 & 242 & & \\
\hline
\end{tabular}

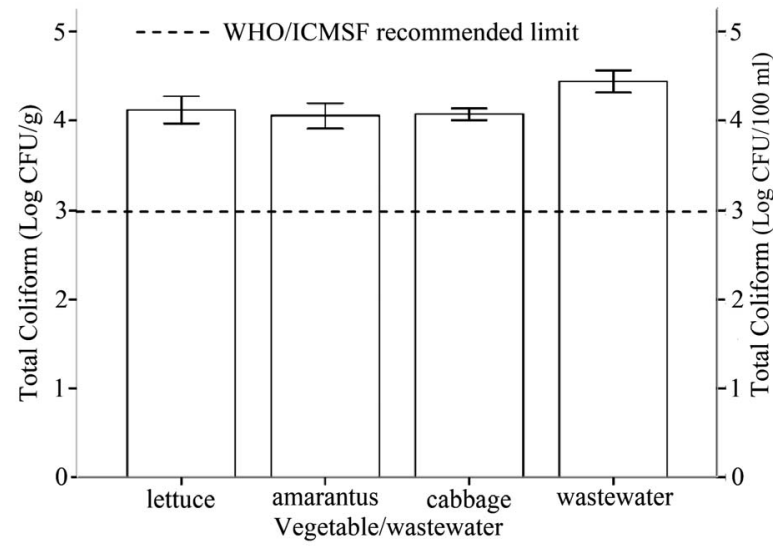

Figure 5. Mean total coliform on vegetables/wastewater.

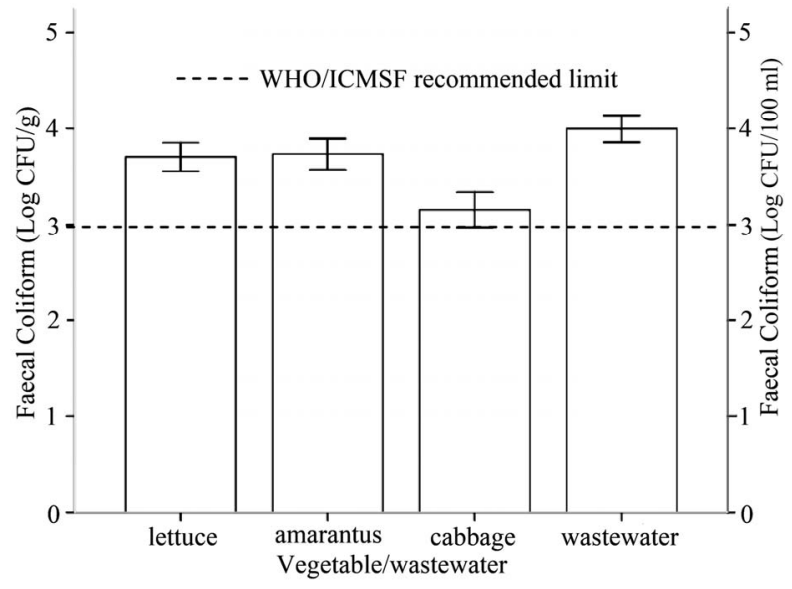

Figure 6. Mean faecal coliform on vegetable/wastewater.

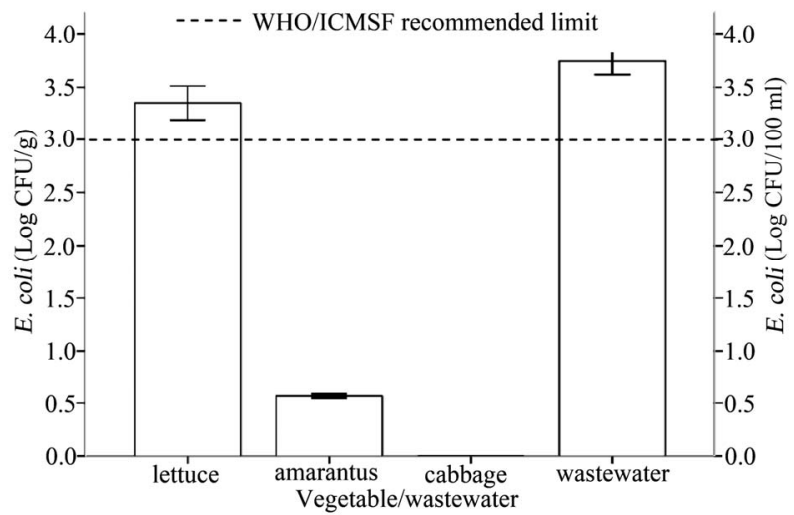

Figure 7. Mean $E$. coli counts on vegetables and wastewater.

figures may not all be as a result of the consumption of contaminated wastewater irrigated vegetables, there is still cause for concern.

\section{Conclusion}

The consumption of vegetables serves as a vital source of much needed minerals and vitamins for the sound deve- 
Table 5. Correlation matrix for faecal coliforms on vegetables and wastewater.

\begin{tabular}{cccccc}
\hline & \multicolumn{5}{c}{ Year } \\
\hline Disease & 2008 & 2009 & 2010 & 2011 & 2012 \\
Typhoid fever & 673 & 2,740 & 1,799 & 3,023 & 56 \\
Cholera & 5 & 2 & 20 & 0 & 0 \\
Diarrhoea & 10,661 & 10,437 & 9,536 & 16,654 & 5,167 \\
Intestinal worms & 3,587 & 3,245 & 3,519 & 4,799 & 204 \\
\hline
\end{tabular}

Source: Ghana Health Service, Northern Region. (Note: Data for 2012 was from Jan-Mar).

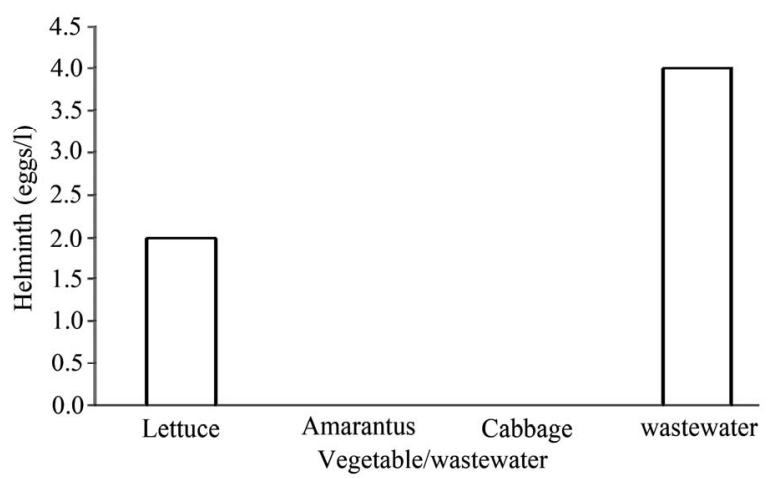

Figure 8. Helminths eggs in vegetable/wastewater.

lopment of the human body. The study shows that microbial loads on vegetables and in wastewater in this part of the Tamale Metropolis were well above ICSFM and WHOs recommended limits for vegetables and wastewater respectively. People who eat these contaminated vegetables raw, stand a high chance of contracting gastrointestinal diseases. To prevent an eminent outbreak efforts have to be made to discouraged farmers from the use of wastewater for irrigation. If they are to use continue with the usage of wastewater, then they have to be educated on good agricultural practices such as modification of the current manual irrigation system to reduce vegetables contact with the polluted irrigated water. Legislation against wastewater use for irrigation could be improved as well as education of farmers on pre-harvesting practices that will help reduce microbial loads on the vegetables. Government and non-government agencies are entreated to provide alternative water sources such as boreholes and hand dug wells on the farms for watering of the vegetables to safeguard the health of consumers.

\section{Acknowledgements}

The team is grateful to staff of CSIR Water Research Institute who helped in the laboratory analysis. We acknowledge the cooperation and help of vegetable farmers at the Gumbihini Waterworks area.

\section{REFERENCES}

[1] C. A. Scott, N. I. Faruqui and L. Raschid-Sally, "Wastewater Use in Irrigated Agriculture: Confronting the Livelihood and Environmental Realities," CABI, Wallingford, 2004.

[2] F. Sabiena, H. Raheela and Van der H. Wim, "Health Risks of Irrigation with Untreated Urban Wastewater in the Southern Punjab, Pakistan," Institute of Public Health (IPH) and International Water Management Institute (IWMI) Research Report No. 107, 2000.

[3] G. B. Shende and C. Chakrabarti, "Optimum Utilization of Municipal Wastewaters as a Source of Fertilizer," Journal of Resources and Conservation, Vol. 13, No. 2-4, 1987, pp. 281-290. doi:10.1016/0166-3097(87)90070-8

[4] Ghana Statistical Services, "2000 Population and Housing Census: Summary Report of Final Results," Ghana Statistical Services, Legon, Accra, 2002.

[5] B. Keraita, P. Drechsel, F. Huibers and L. Raschid-Sally, "Wastewater Use in Informal Irrigation in Urban and Peri-Urban Areas of Kumasi, Ghana," Urban Agriculture Magazine, No. 8, 2002, pp. 11-13.

[6] P. Amoah, P. Drechsel and R. C. Abaidoo, "Irrigated Urban Vegetable Production in Ghana: Sources of Pathogen Contamination and Health Risk Reduction," Irrigation Drainage, Vol. 54, No. S1, 2005, pp. 49-61. doi:10.1002/ird.185

[7] R. C. Abaidoo, B. Keraita, P. Amoah, P. Drechsel, J. Bakang, G. Kranjac-Berisavljevic, F. Konradsen, W. Agyekum and A. Klutse, "Safeguarding Public Health Concerns, Livelihoods and Productivity in Wastewater Irrigated Urban and Peri-Urban Vegetable Farming," CPWF PN 38 Project Report, Kumasi, 2009.

[8] M. A. S. McMaho and I. G. Wilson, "The Occurrence of Enteric Pathogens and Aeromonas Species in Organic Vegetables," International Journal of Food Microbiology, Vol. 70, No. 1-2, 2001, pp. 155-162. doi:10.1016/S0168-1605(01)00535-9

[9] L. R. Beuchat, "Food Safety Issues: Surface Decontamination of Fruits and Vegetables Eaten Raw: A Review," Food Safety Unit, WHO, Geneva, 1999.

[10] P. Amoah, P. Drechsel, R. C. Abaidoo and M. Henseler, "Irrigated Urban Vegetable Production in Ghana: Microbiological Contamination in Farms and Markets and Associated Consumer Risk Groups," Journal for Water and Health, Vol. 5, No. 3, 2007, pp. 455-466. doi: $10.2166 /$ wh.2007.041

[11] D. D. Mara, P. A. Sleigh, U. J. Blumenthaland and R. M. Carr, "Health Risks in Wastewater Irrigation: Comparing Estimates from Quantitative Microbial Risk Analyses and Epidemiological Studies," Journal of Water and Health, Vol. 5, No. 1, 2007, pp. 39-50. doi:10.2166/wh.2006.055

[12] J. H. J. Ensink, "Water Quality and the Risk of Hookworm Infection in Pakistani and Indian Sewage Farmers," Ph.D. Thesis, University of London, London, 2006.

[13] J. A. Frost, M. B. McEvoy, C. A. Bently, Y. Andersson and B. Rowe, "An Outbreak of Shigella sonnei Infection Associated with Consumption of Iceberg," Emerging In- 
fectious Disease, Vol. 1, No. 1, 1995, pp. 26-28. doi:10.3201/eid0101.950105

[14] K. Takeuchi, A. N. Hassan and J. F. Frank, "Penetration of Escherichia coli O157:H7 into Lettuce as Influence by Modified Atmosphere and Temperature," Journal of Food Protection, Vol. 64, No. 11, 2001, pp. 1820-1823.

[15] S. Abdul-Ghaniyu, G. Kranjac-Berisavljevic, I. B. Yakubu and B. Keraita, "Sources and Quality of Water Used in Urban Vegetable Production in Tamale Municipality, Ghana," AU Magazine no.8-Wastewater Reuse in Urban Agriculture, 2005.

[16] APHA, AWWA, WEF, "Standard Methods for the Examination of Water and Wastewater," 20th Edition, American Water Works Association, Denver, 1998.

[17] J. Schwartzbrod, "Methods of Analysis of Helminth Eggs and Cysts in Wastewater, Sludge, Soil and Crops," University Henry Poincare, Nancy, 1998.

[18] World Health Organization, "Guidelines for Drinking Water Quality," First Addendum to 3rd Edition, Recommendations, Vol. 1, 1993, p. 444.

[19] N. O. B. Ackerson and E. Awuah, "Microbial Risk Assessment of Urban Agricultural Farming: A Case Study on Kwame Nkrumah University of Science and Technology Campus, Kumasi, Ghana," International Journal of Science and Technology, Vol. 1, No. 3, 2012, pp. 118125.

[20] M. A. Halablab, I. H. Sheet and H. M. Holail, "Microbiological Quality of Raw Vegetables Grown in Bekaa Valley, Lebanon," American Journal of Food Technology, Vol. 6, No. 2, 2011, pp. 129-139. doi:10.3923/ajft.2011.129.139

[21] L. R. Beuchat, "Ecological Factors Influencing Survival and Growth of Human Pathogens on Raw Fruits and Vegetables," Microbial Infections, Vol. 4, No. 4, 2002, pp. 413-423. doi:10.1016/S1286-4579(02)01555-1

[22] J. Spencer, H. R. Smith and H. Chart, "Characterization of Enteroaggregative Escherichia coli Isolated from Outbreaks of Diarrhoeal Disease in England," Epidemiology and Infection, Vol. 123, No. 3, 1999, pp. 413-421. doi:10.1017/S0950268899002976

[23] S. M. Faruque, M. J. Albert and J. J. Mekalanos, "Epidemiology, Genetics and Ecology of Toxigenic Vibrio Cholerae," Microbiology and Molecular Biology Reviews, Vol. 62, No. 4, 1998, pp. 1301-1314.

[24] P. S. Mead and P. M. Griffin, "Escherichia coli O157:H7," Lancet, Vol. 352, No. 9135, 1998, pp. 1207-1212. doi:10.1016/S0140-6736(98)01267-7

[25] H. Michino, K. Araki, S. Minami, et al., "Massive outbreak of Escherichia coli O157:H7 Infection in School Children, Sakai City, Japan, Associated with Consumption of White Radish Sprouts" American Journal Epidemiology, Vol. 150, No. 8, 1999, pp. 787-796. doi:10.1093/oxfordjournals.aje.a010082

[26] H. I. Shuval, "Health Guidelines and Standards for Wastewater Reuse in Agriculture: Historical Perspectives," Water Science and Technology, Vol. 23, No. 10-12, 1991, pp. 2037-2080.

[27] World Health Organization, "Health Guidelines for the Use of Wastewater in Agriculture and Aquaculture," Technical Report Series No. 778. WHO Scientific Group, Geneva, 1989.

[28] World Health Organisation, "Guidelines for the Use of Wastewater Excreta and Grey Water: Wastewater Use in Agriculture," Vol. 1, 2, 4, WHO, Geneva, 2006. 